\title{
Flora of the Kharbey Lakes (the East of Bolshezemelskaya Tundra)
}

\author{
Boris Yu. Teteryuk* \\ Institute of Biology, Komi Scientific Centre, UB RAS \\ 28 Kommunisticheskaya Str., Syktyvkar, GSP-2, 167982, Russia
}

Received 04.05.2014, received in revised form 11.07.2014, accepted 02.08.2014

The paper contains the data on composition and structure of the Kharbey Lakes' flora (the east of Bolshezemelskaya tundra) and its specific features. Flora of the Kharbey Lakes includes 91 species. Among them, there are 65 species of vascular plants, 25 species of bryophytes, and 1 species of charophytes. Potamogeton subretusus, which is a rare species for the European North-East of Russia, was found in shallow places of the Bolshoi Kharbey Lake. The Poaceae, Potamogetonaceae, Cyperaceae and Ranunculaceae families among vascular plants and Calliergonaceae, Sphagnaceae and Mniaceae among bryophytes have the greatest number of species. In the hydroecological aspect, vascular plants and bryophytes are dominated by hygrophytes. From the trophoecological point of view, flora usually includes mesotrophic groups of plants. By its geographical structure, the Kharbey Lakes' flora corresponds with its zonal position as vascular plants are dominated by representatives of the Arctic-temperate latitude group and bryophytic plants are dominated by the boreal group with some hypo-arctic species.

Keywords: flora of water bodies, aquatic plants.

\section{Флора озёр Харбейской системы (восток Болышеземельской тундры)}

\section{Б.Ю. Тетерюк \\ Институт биологии Коми НЦ УрО РАН} Россия, 167982, ГСП-2, Сыктывкар, Коммунистическая, 28

В статье представлены результаты изучения состава и структуры флоры Харбейских озёр (восток Большеземельской тундры) и выявления её характерных особенностей. Флору

(C) Siberian Federal University. All rights reserved

* Corresponding author E-mail address: b_teteryuk@ib.komisc.ru 
Харбейской озёрной системы формирует 91 вид. Из них 65 видов сосудистых растений, 25 видов мохообразных и 1 вид харовых водорослей. На мелководьях оз. Большой Харбей отмечен редкий для Европейского Северо-Востока России вид - Potamogeton subretusus. Ведущие позичии по числу видов среди сосудистых растений занимают семейства Poaceae, Potaтоgetonaceae, Cyperaceae и Ranunculaceae. Среди мохообразных-Calliergonaceae, Sphagnaceae и Mniaceae. B гидроэкологическом спектре флоры сосудистых растений и мохообразных наблюдается явное преобладание гигрофитов. Соотношение трофоэкологических групп флоры демонстрирует её приуроченность к мезотрофным местообитаниям. Географическая структура флоры Харбейских озёр -как сосудистых, так и мохообразных - в полноймере отражает их зональное положение: среди сосудистых преобладают виды арктоумеренной широтной группы, среди мохообразных - бореальной с участием гипоарктических видов.

Ключевые слова: флора водоёмов, водные растения.

\section{Введение}

Тундры Европейского Северо-Востока России в силу особенностей своего климата и геологической истории богаты различного рода водными объектами (Алисов, 1969; Флора и фауна, 1978; Атлас по климату..., 1997). Особое внимание привлекают крупные озёрные системы, являющиеся своего рода центрами биоразнообразия гидроэкосистем Заполярья (Флора и фауна, 1978).

Известно, что состав и структура растительного покрова водоёма в полной мере отражают как современное экологическое состояние гидроэкосистемы, так и историю её становления (Одум, 1975).

Цель настоящей статьи заключается в обобщении сведений о составе и структуре флоры Харбейских озёр и выявлении её характерных особенностей.

\section{Материалы и методы}

Район работ

Харбейская озерная система расположена в восточной части Большеземельской тундры на границе между Республикой Коми и Ненецким АО Архангельской обл. Координаты оз. Большой Харбей - 67³3' с.ш., $62^{\circ} 53^{\prime}$ в.д.
Согласно ботанико-географическому районированию европейской части России (Растительность..., 1980) озерная система располагается в ЕвропейскоЗападносибирской тундровой провинции в пределах Циркумполярной тундровой области. В соответствии с региональным геоботаническим районированием (Юдин, 1954) она лежит в тундровой зоне, подзоне кустарниковой тундры.

\section{Методы сбора и анализа материала}

«Флора водоёма» понимается как совокупность видов водных и береговых растений, закономерно встречающихся в водоёме (водотоке) (Папченков и др., 2006). Ядро флоры составляют виды, входящие в экологические группы гидро-, гело- и гигрогелофитов (Папченков, 2001).

Определяющее значение при отнесении вида к данному компоненту региональной флоры имеет естественно обусловленный факт его присутствия в составе сообществ или открытых растительных группировок, характерных для гидроморфных (околоводных, прибрежно-водных и водных) экотопов, т.е. используется экоценотический критерий (Тетерюк, 2006). 
Флору озёр Харбейской системы (оз. Большой Харбей, оз. Головка и группа малых озёр к северо-востоку от оз. Большой Харбей) изучали в 2010 г. согласно методическим разработкам для гидроботанических исследований (Катанская, 1981; Щербаков, 2003). Основу флористического списка составили видовые списки геоботанических описаний (всего 78 описаний) и сборы вне площадок описаний. Дополнительно к анализу привлечены материалы Гербария Института биологии Коми НЦ УрО РАН (SYKO). Также для анализа флоры использованы данные из монографии «Флора и фауна водоёмов Европейского Севера» (1978).

Видовой состав документирован гербарными сборами, хранящимися в SYKO. Всего собрано 112 гербарных листов сосудистых растений и 36 многовидовых пакетов мохообразных.

Сборы мохообразных выполнены автором, их определение - д.б.н. Г.В. Железновой (ИБ Коми НЦ УрО РАН).

Принятая в работе система географических групп сосудистых растений основана на преимущественном распространении вида в пределах долготных секторов и широтных зон Северного полушария. Выделение географических элементов листостебельных мхов дано по системе А.С. Лазаренко (1956) и Р.Н. Шлякова (1961).

Экологические группы сосудистых растений выделены на основе стандартных экологических шкал (Раменский и др., 1956). Названия гидроэкогрупп и критерии их выделения даны по Л.Г. Раменскому с соавт. (1956) и В.Г. Папченкову (2001). Названия трофоэкогрупп - по Л.Г. Раменскому с соавт. (1956) и Ю.В. Титову (1975). Экологические группы мохообразных перечислены с использованием работ Г.В. Железновой (1994).
Показатели встречаемости вида определены исходя из его присутствия в массиве геоботанических описаний, характеризующих соответствующий класс экотопов (водные местообитания и береговые местообитания). Более подробно методика описана в монографии о флоре и растительности древних озёр региона (Тетерюк, 2012б). Частота встречаемости видов дана в следующих градациях: обычно вид отмечен в 76-100 \% геоботанических описаний, часто - в 51-75 \% описаний, умеренно - в 26-50 \% описаний, спорадически - в 16-25\% описаний, редко - в 6-15\% описаний, очень редко - менее чем в $6 \%$ описаний или имеются лишь единичные находки вида вне площадок описаний либо литературные данные.

Латинские названия таксонов сосудистых растений приведены по сводке С.К. Черепанова (1995), мохообразных - согласно сводке М.С. Игнатова, О.М. Афониной и Е.А. Игнатовой (2006).

\section{Результаты и обсуждение}

Анализ литературных сведений о флоpe озёр Харбейской системы (Мартыненко, Гецен, 1978), материалов гербарных фондов (SYKO) и данных собственных полевых сборов позволил нам установить, что флору озёрной системы формирует 91 вид. Из них 65 видов сосудистых растений, 25 видов мохообразных и 1 вид харовых водорослей. Это значительно (на 24 вида) больше, чем в одном только оз. Большой Харбей (Тетерюк, 2012а). Флористическое разнообразие отражено в табл. 1.

Основу видового списка составили наши сборы. В ходе полевых исследований нами не было подтверждено нахождение ранее указывавшихся для флоры Харбейских озёр (Мартыненко, Гецен, 1978) таких гидрофитов, как Ceratophyllum demersum L., Myriophyllum spicatum L., M. verticillatum L., 
Таблица 1. Показатели таксономического разнообразия флоры Харбейских озёр

\begin{tabular}{|c|c|c|c|c|}
\hline & $\begin{array}{c}\text { Сосудистые } \\
\text { растения }\end{array}$ & $\begin{array}{c}\text { Мохооб- } \\
\text { разные }\end{array}$ & $\begin{array}{c}\text { Высшие } \\
\text { водоросли }\end{array}$ & $\begin{array}{c}\text { Флора } \\
\text { в целом }\end{array}$ \\
\hline Общее число видов & 65 & 25 & 1 & 91 \\
\hline Общее число родов & 41 & 16 & 1 & 58 \\
\hline Общее число семейств & 28 & 12 & 1 & 41 \\
\hline Число одновидовых родов & 28 & 10 & 1 & 39 \\
\hline Доля одновидовых родов, \% & 68.3 & 62.5 & 100.0 & 67.2 \\
\hline Число одновидовых семейств & 15 & 6 & 1 & 22 \\
\hline Доля одновидовых семейств, \% & 53.6 & 50.0 & 100.0 & 53.7 \\
\hline Макс. число видов в одном роде & 7 & 4 & 1 & 7 \\
\hline Макс. число видов в одном семействе & 8 & 5 & 1 & 8 \\
\hline Макс. число родов в одном семействе & 5 & 3 & 1 & 5 \\
\hline Доля видов в 3 ведущих семействах, \% & 33.8 & 52.0 & - & 24.2 \\
\hline Доля видов в 5 ведущих семействах, \% & 47.7 & 60.0 & - & 37.4 \\
\hline Доля видов в 10 ведущих семействах, \% & 67.7 & 92.0 & - & 55.6 \\
\hline Доля высших водорослей, \% & - & - & 100.0 & 1.1 \\
\hline Доля мхов, \% & - & 100.0 & - & 27.5 \\
\hline Доля сосудистых споровых, \% & 4.6 & - & - & 3.3 \\
\hline Доля цветковых, \% & 95.4 & - & - & 68.1 \\
\hline Доля однодольных среди цветковых, \% & 43.6 & - & - & 43.6 \\
\hline Доля двудольных среди цветковых, \% & 56.5 & - & - & 56.5 \\
\hline
\end{tabular}

Batrachium trichophyllum (Chaix) Bosch (у авторов B. divaricatum (Schrank) Schur). Общий список был дополнен четырнадцатью видами (см. аннотированный список). Potamogeton praelongus Wulf. не отмечен автором в ходе полевых работ, но в коллекциях Гербария SYKO имеются его сборы из оз. Большой Харбей (27.VII.1968 г., Э.И. Попова; 4.VII.1968 г., М.В. Гецен, Э.И. Кочанова; 16.VII.1968 г., М.В. Гецен, Э.И. Кочанова; VIII.1969 г., Э.И. Попова). На этом основании вид включён в аннотированный список.

Анализ данных о сосудистых, мохообразных и макроводорослях приводим раздельно в силу специфичности каждой из групп

\section{Сосудистые растения}

Аннотированный список

Принятые в аннотированном списке флоры сокращения. Гидроэкогруппы: ГД - гидро- фиты, ГЛ - гелофиты, ГГЛ - гигрогелофиты, ГГ - гигрофиты, ГМ - гигромезофиты, М мезофиты, КМ - ксеромезофиты. Трофоэкогруппы: ЭТ - эвтрофы, МЭТ - мезоэвтрофы, МТ - мезотрофы, МОТ - мезоолиготрофы, ОТ - олиготрофы, ГГа - гипогалофиты. Долготные географические группы: Космополитная фракиия: косм. - космополитная; Голарктическая фракция: ЦП - циркумполярная, ЦБ - циркумбореальная, сЦБ - субциркумбореальная, с.ам.-евр.-з.аз. - североамериканскоевропейско-западноазиатская, с.ам.-евр.-сиб. североамериканско-европейско-сибирская, евраз.-с.ам.-австрал. - евразиатско-североамериканско-австралийская, с. и в. евр.аз.-с.ам. - северо- и восточноевропейскоазиатско-североамериканская, в.евр.-аз.-с. ам - восточноевропейско-азиатскосевероамериканская, с.ам.-евр. с ев ероа ме риканско-европейская ; 
Евразиатская фракция: в.евр.-з. сиб. восточноевропейская _ - западносибирская, евраз. - евразиатская, евр.-з. аз. - европейско-западноазиатская, евр.-сиб. европейско-сибирская, с. и в.евр.-аз. - северо- и восточноевропейско-азиатская, с. и в. евр.-з.аз. - северо- и восточноевропейскозападноазиатская; Европейская фракция: евр. - европейская, с. и в. евр. - северо- и восточноевропейская. Широтные географические группы: а.ум.стр. - аркто-умеренная и субтропическая, а.ум. - арктоумеренная, ум. - умеренная, га - гипоарктическая, а - арктическая, плюр - плюризональная.

Сем. Apiaceae: Angelica archangelica L. М, МЭТ, евр.-3.аз., ум., редко.

Сем. Asteraceae: Petasites frigidus (L.) Fries - ГГ, МТ, с. и в. евр.-аз.-с.ам., а.ум., очень редко; P. radiatus (J.F.Gmel.) Holub ГГЛ, МЭТ, в. евр.-з.сиб., а. ум., редко; Solidago virgaurea L. - M, MT, евр.- з.аз., а. ум., очень редко.

Сем. Boraginaceae: Myosotis palustris (L.) L. - ГГ, МЭТ, с.ам.-евр.-3.аз., а.ум., умеренно.

Сем. Brassicaceae: Cardamine pratensis L. - ГГ, МЭТ, евр., а.ум., умеренно.

Сем. Callitrichaceae: Callitriche hermaphroditica L. - ГГ, МЭТ, ЦБ, а.ум., очень редко; C. palustris L. - ГГ, МЭТ, евраз.-с.ам.австрал., а.ум., редко.

Сем. Caryophyllaceae: Stellaria palustris Retz. - ГМ, МЭТ, евраз., ум., умеренно.

Сем. Cyperaceae: Carex acuta L. - ГГ, МЭТ, евраз., а.ум., очень редко; C. aquatilis Wahlenb. - ГГЛ, МТ, сЦБ, а.ум., обычно; C. arctisibirica (Jurtz.) Czer. - ГГЛ, МТ, с.ам.евр., а., очень редко; C. cinerea Poll. - ГГ, МТ, ЦБ, а.ум.стр., редко; C.juncella (Fries) Th.Fries ГГ, МТ, евр., а. ум., редко; Eleocharis acicularis (L.) Roem. et Schult. - ГГЛ, МЭТ, ЦБ, а. ум., часто; Eriophorum scheuchzeri Hoppe - ГМ, МТ,
ЦП, га, редко; E. vaginatum L. - ГГ, ОТ, ЦБ, а. ум., редко.

Сем. Equisetaceae: Equisetum arvense L. - M, МЭТ, ЦБ, ум., умеренно; E. fluviatile L. - ГЛ, МЭТ, ЦБ, а.ум., редко ; E. palustre L. ГГ, МТ, ЦБ, а.ум., редко.

Сем. Haloragaceae: Myriophyllum sibiricum Kom. - ГД, МЭТ, с. и в.евр.-аз.-с.ам., а.ум., редко.

Сем. Geraniaceae: Geranium albiflorum Ledeb. - ГM, MT, в.евр.-з. сиб., очень редКо.

Сем. Hippuridaceae: Hippuris vulgaris L. - ГГЛ, МЭТ, косм., плюр., редко.

Сем. Juncaceae: Juncus filiformis L. $-\Gamma \Gamma$, МЭТ, ЦБ, а.ум., очень редко; Luzula confusa Lindeb. - КМ, МТ, ЦП, га, редко.

Сем. Lemnaceae: Lemna trisulca L. - ГД, ЭТ, косм, плюр., редко.

Сем. Melanthiaceae: Veratrum lobelianum Bernh. - М, МЭТ, ЦБ, ум., редко.

Сем. Onagraceae: Chamaenerion angustifolium (L.) Scop - M, МТ, ЦБ, а.ум., очень редко; Epilobium palustre L. - ГГ, МЭТ, ЦБ, а.ум., умеренно.

Сем. Parnassiaceae: Parnassia palustris L. - ГМ, МТ, ЦБ, а.ум., очень редко.

Сем. Poaceae: Alopecurus aequalis Sobol. - ГГ, ЭТ, ЦБ, ум., редко; A. pratensis L. - M, ЭТ, евраз., а. ум., очень редко; Arctophila fulva (Trin.) Anderss. - ГЛ, МЭТ, ЦП, га, умеренно; Calamagrostis holmii Lange - ГМ, MT, с. ам.- евр.-сиб., а, редко; C. neglecta (Ehrh.) Gaertn. - ГГ, МТ, ЦБ, а.ум., умеренно; C. purpurea (Trin.) Trin. - ГМ, МЭТ, с. и в.евр.-аз., а.ум., редко; Hierochlö odorata (L.) Beauv. - ГМ, МЭТ, ЦП, га, очень редко; Poa pratensis L. - M, МЭТ, ЦБ, а.ум., редко.

Сем. Polygonaceae: Bistorta major S.F.Gray - M, MT, евраз., ум., очень редко; B. vivipara (L.) S.F.Gray - M, МЭТ, ЦБ, а.ум., 
редко; Rumex acetosa L. - М, МЭТ, ЦБ, ум., очень редко; R. aquaticus L. - ГГЛ, МЭТ, евраз., а.ум., очень редко.

Сем. Potamogetonaceae: Potamogeton alpinus Balb. - ГД, МЭТ, ЦБ, а.ум., редко; P. berchtoldii Fieb. - ГД, МЭТ, ЦБ, а.ум., редко; P. gramineus L. - ГД, МЭТ, ЦБ, а.ум., умеренно; $P . \times$ nitens Web. (P. gramineus $\times$ P. perfoliatus $)-$ ГД, МЭТ, ЦБ, а.ум., очень редко; P. perfoliatus L. - ГД, МЭТ, ЦБ, а.ум., спорадически; P. praelongus Wulf. - ГД, МЭТ, ЦБ, а.ум., очень редко; P. subretusus Hagstr. - ГД, МТ, в.евр.аз.-с.ам., а.ум., редко.

Сем. Ranunculaceae: Batrachium eradicatum (Laest.) Fries - ГД, МЭТ, с. и в. евр. аз.-с.ам., а.ум., очень редко; Caltha palustris L. -ГГЛ, МЭТ, ЦБ, а.ум., умеренно; Ranunculus hyperboreus Rottb. - ГГЛ, МОТ, ЦП, а, редко; $R$. repens L. - ГГ, ЭТ, евр.- з.аз., а.ум., спорадически; R. reptans L. - ГЛ, МЭТ, ЦБ, а.ум., умеренно; R. subborealis Tzvel. - ГМ, МЭТ, с. и в. евр.-з.аз., а.ум., очень редко.

Cem. Rosaceae: Comarum palustre L. ГГЛ, МТ, ЦБ, а.ум., умеренно; Rubus arcticus L. - ГМ, МТ, с. и в.евр.- аз.- с.ам., а.ум., очень редко.

Cем. Rubiaceae: Galium palustre L. - ГГ, МЭТ, с.ам.- евр.- з.аз., ум., спорадически; G. uliginosum L. - ГГ, МЭТ, евр.- з.аз., а.ум., редко.

Ceм. Salicaceae: Salix lanata L. - ГМ, MT, евр.- сиб., га, редко; S. phylicifolia L. - ГМ, MT, с. и в. евр., а.ум., редко.

Cем. Saxifragaceae: Chrysosplenium alternifolium L. - ГГ, МТ, ЦБ, а.ум., редко.

Сем. Scrophulariaceae: Veronica longifolia L. - ГМ, МЭТ, ЦБ, а.ум., умеренно.

Cем. Sparganiaceae: Sparganium hyperboreum Laest. - ГЛ, МТ, ЦП, га, спорадически.

Сем. Violaceae: Viola epipsila Ledeb. ГМ, МТ, с. и в. евр.-з.аз., ум., редко.
Сосудистые растения флоры Харбейских озёр являются представителями 41 рода и 28 семейств. Численно флора озёр составляет $12,7 \%$ от общего состава флоры тундровой зоны Европейского Северо-Востока России (Мартыненко и др., 1987). В её составе преобладают цветковые двудольные растения (табл. 1). На мелководьях оз. Большой Харбей отмечен редкий для Европейского СевероВостока России вид - Potamogeton subretusus.

Наибольшим видовым разнообразием обладают семейства Pоасеае (8 видов), Potamogetonaceae (7), Cyperaceae (7), Ranunculaceae (6), Polygonaceae (4), Asteraceae (3), Equisetaceae (3). В состав этих семи семейств входит почти две трети (58,5 \%) всех видов флоры. Преобладание во флоре семейств Poaceae, Cyperaceae, Ranunculaceae, Polygonaceae и Asteraceae свойственно для флор тундровых районов Европейского Северо-Востока России (Ребристая, 1977; Мартыненко и др., 1987; Секретарёва, 2004). Принадлежность к гидрофитным флорам подчёркивает присутствие в числе ведущих семейства Potamogetonaceae. Однако в отличие от флор крупных озёр таёжной зоны региона рдестовые являются единственным гидроспециализированным (представленным только водными видами) семейством из числа ведущих в рассматриваемой флоре (Тетерюк, 2012б).

Среди наиболее представленных во флоpe Харбейских озёр роды: Potamogeton (7), Carex (4), Calamagrostis (3), Equisetum (3).

Специфику флоры отражает распределение видов по экологическим группам (табл. 2). Почти на треть (29,2 \%) рассматриваемая флора состоит из гигрофитов (видов, приуроченных к сырым, переувлажнённым экотопам). Более трети (35,4 \%) приходится на долю видов гидрофитного ядра (гидрофиты, гелофиты и гигрогелофиты вместе взятые). 
Таблица 2. Распределение числа видов сосудистых растений флоры Харбейских озёр по гидроэкогруппам

\begin{tabular}{l|c|c}
\hline \multicolumn{1}{c|}{ Гидроэкогруппа } & Число видов, шт. & Доля, \% \\
\hline Гидрофиты & 10 & 15.5 \\
Гелофиты & 4 & 6.2 \\
Гигрогелофиты & 9 & 13.8 \\
Гигрофиты & 19 & 29.2 \\
Гигромезофиты & 13 & 20.0 \\
Мезофиты & 9 & 13.8 \\
Ксеромезофиты & 1 & 1.5 \\
Всего: & 65 & 100.0 \\
Ядро флоры* & 23 & 35.4 \\
\hline
\end{tabular}

*Гидрофитное ядро флоры - гидрофиты, гелофиты и гигрогелофиты вместе взятые.

Как правило, во флорах водоёмов доля видов водного ядра значительно больше (Свириденко, 2000; Папченков, 2001; Тетерюк, 2012а, 2012б). В таёжной зоне преобладание во флоре гигрофильных видов в большей степени свойственно для водотоков (Бобров, 1999). Для флор водоёмов тундровой зоны, возможно, эта закономерность связана с усилением экстремальности условий для гидрофитов, что обусловливает уменьшение доли их участия во флоре Харбейских озёр.

Относительно высокий процент во флоре озёр мезофитов $(13,8 \%)$ и гигромезофитов (20,0 \%) обусловлен как особенностями самих тундровых озёр, так и спецификой их береговых экотопов. Большая часть гигромезо- и мезофитов приурочена к обсыхающим мелководьям и сырым пологим берегам мелководных термокарстовых озёр. Во флоре крупных озёр (Большой Харбей) доля этих гидрогрупп составляет 12,5 и $0 \%$ соответственно (Тетерюк, 2012a). Однако следует отметить, что представители этих экологических групп (Alopecurus pratensis, Poa pratensis, Solidago virgaurea, Veratrum lobelianum, Parnassia palustris и др.) весьма широко распространены в пойменных приозёрных луговинах Большеземельской тундры, нередко образуя густые заросли (Хантимер, 1974; Ребристая, 1977). В береговых ценозах (водяноосоковых, северолюбковых, осково-сабельниковых и др.), как сомкнутых, так и разреженных, мезо- и гигромезофиты весьма редкий компонент (см. аннотированный список сосудистых растений флоры) и обычно это единичные особи.

В экологическом спектре флоры сосудистых растений хорошо проявляется ее приуроченность к мезоэвтрофным местообитаниям (табл. 3). Чуть более половины (55,4 \%) видов входят в состав мезоэвтрофной и $35,4 \%$ видов - мезотрофной экогрупп.

Локализация озёр Харбейской озёрной системы в высоких широтах обусловливает преобладание в составе её флоры видов арктоумеренной широтной группы (69,2\%) (табл. 4). Вместе с тем высока доля видов гипоарктической $(10,8 \%)$ и умеренной $(13,9 \%)$ групп, что демонстрирует наличие контактов с гидросистемами как таёжной, так арктической зон.

\section{Мохообразныле}

Выявленные нами в составе флоры Харбейской озёрной системы мохообразные отно- 
Таблица 3. Распределение числа видов сосудистых растений флоры Харбейских озёр по трофоэкогруппам

\begin{tabular}{l|c|c}
\hline \multicolumn{1}{c|}{ Трофоэкогруппа } & Число видов, шт. & Доля, \% \\
\hline Эвтрофы & 4 & 6.2 \\
Мезоэвтрофы & 36 & 55.4 \\
Мезотрофы & 23 & 35.4 \\
Мезоолиготрофы & 1 & 1.5 \\
Олиготрофы & 1 & 1.5 \\
Всего: & 65 & 100.0 \\
\hline
\end{tabular}

сятся к двум классам (Bryopsida и Hepaticae). Ниже приводится их аннотированный список.

Принятые сокращения. Экология: ГД гидрофиты, ГГД-гигрогидрофит, ГГ-гигрофиты, ГМ - гигромезофиты, М - мезофиты. Широтные географические группы: б - бореальная, г - горная, га - гипоарктическая, аa - арктоальпийская, п - плюризональная. Долготные географические группы: ц - циркумполярная, бп - биполярная, к - космополитная.

\section{BRYOPSIDA:}

Сем. Sphagnaceae: Sphagnum flexuosum Dozy et Molk. - ГГ, б, ц, редко; S. girgensohnii Russow - ГГ, б, ц, очень редко; S. obtusum Warnst. - ГД, б, ц, редко; S. subsecundum Nees - ГД, б, ц, очень редко.

Сем. Polytrichaceae: Polytrichum swartzii Hartm. - М, га, ц, очень редко.

Сем. Bryaceae: Bryum pseudotriquetrum (Hedw.) Gaertn. et al. - ГД, б, бп, редко.

Сем. Mniaceae: Mnium stellare Hedw. M, б, ц, редко; Plagiomnium curvatulum (Lindb.) Schljakov-м, га, ц, редко; P. ellipticum (Brid.) T. J. Кор. - ГМ, б, ц, спорадически; Pseudobryum cinclidioides (Huebener) T.J. Kop. - ГГ, га, ц, редко.

Сем.Fontinaliaceae:Fontinalisantipyretica var. gracilis (Lindb.) Schimp. - ГД, г, ц, спора- дически; F. hypnoides Hartm. - ГД, б, ц, очень редко.

Cем. Bartramiaceae: Philonotis caespitosa Jur. - ГГ, б, ц, очень редко; P. tomentella Molendo - ГГ, аа, ц, редко.

Сем. Climaciaceae: Climacium dendroides (Hedw.) Weber et Mohr - ГM, б, ц, редко.

Сем. Amblystegiaceae: Drepanocladus sendtneri (Schimp. ex H. Mull.) Warnst. ГГД, б, ц, редко; Leptodictyum riparium (Hedw.) Warnst. - ГД, б, бп, редко.

Сем. Calliergonaceae: Calliergon cordifolium (Hedw.) Kindb. - ГГ, б, бп, умеренно; C. megalophyllum Mikut. - ГГ, б, ц, редко; Calliergon stramineum (Brid.) Kindb. - ГД, га, ц, очень редко; Warnstorfia exannulata (Bruch et al.) Loeske - ГД, б, ц, умеренно; W. fluitans (Hedw.) Loeske - ГГ, б, ц, очень редко.

Сем. Brachytheciaceae: Brachythecium salebrosum (Weber et Mohr) - М, б, ц, очень редко.

Сем. Pylaisiaceae: Calliergonella lindbergii (Mitt.) Hedenas - ГГ, б, ц, редко.

\section{HEPATICAE:}

Сем. Marchantiaceae: Marchantia polymorpha L. - ГМ, п, к, спорадически.

Мохообразные представлены 25 видами из 16 родов и 12 семейств (табл. 1), это 15,2\% от общего числа флоры листостебельных мхов 
Таблица 4. Распределение числа видов сосудистых растений флоры Харбейских озёр по географическим группам

\begin{tabular}{|c|c|c|c|c|c|c|}
\hline \multirow{2}{*}{$\begin{array}{c}\text { Широтные } \\
\text { географические группы }\end{array}$} & \multicolumn{4}{|c|}{$\begin{array}{c}\text { Долготные географические группы } \\
\text { (по фракционно*) }\end{array}$} & \multirow{2}{*}{$\begin{array}{c}\text { Число } \\
\text { видов, } \\
\text { шт. }\end{array}$} & \multirow[b]{2}{*}{ Доля, \% } \\
\hline & $\begin{array}{c}\text { Голар- } \\
\text { ктиче- } \\
\text { ская }\end{array}$ & $\begin{array}{l}\text { Евроази- } \\
\text { атская }\end{array}$ & $\begin{array}{l}\text { Европей- } \\
\text { ская }\end{array}$ & $\begin{array}{c}\text { Космо- } \\
\text { политная }\end{array}$ & & \\
\hline Арктическая & 2 & 0 & 0 & 0 & 2 & 3.1 \\
\hline Гипоарктическая & 5 & 2 & 0 & 0 & 7 & 10.8 \\
\hline Арктоумеренная & 32 & 10 & 3 & 0 & 45 & 69.2 \\
\hline Арктоумеренная и субтропическая & 1 & 0 & 0 & 0 & 1 & 1.5 \\
\hline Умеренная & 5 & 4 & 0 & 0 & 9 & 13.9 \\
\hline Плюризональная & 0 & 0 & 0 & 1 & 1 & 1.5 \\
\hline Всего: & 45 & 16 & 3 & 1 & 65 & 100.0 \\
\hline Доля, \% & 69.3 & 24.6 & 4.6 & 1.5 & 100.0 & \\
\hline
\end{tabular}

*Состав фракций дан в примечании к аннотированному списку сосудистых растений

Таблица 5. Распределение числа видов мохообразных флоры Харбейских озёр по географическим группам

\begin{tabular}{|c|c|c|c|c|c|}
\hline \multirow[b]{2}{*}{$\begin{array}{c}\text { Широтные } \\
\text { географические группы }\end{array}$} & \multicolumn{3}{|c|}{ Долготные географические группы } & \multirow[b]{2}{*}{$\begin{array}{l}\text { Число видов, } \\
\text { шт. }\end{array}$} & \multirow[b]{2}{*}{ Доля, \% } \\
\hline & $\begin{array}{l}\text { Циркум- } \\
\text { полярная }\end{array}$ & Биполярная & $\begin{array}{c}\text { Космо- } \\
\text { полит- } \\
\text { ная }\end{array}$ & & \\
\hline Арктоальпийская & 1 & - & - & 1 & 4.0 \\
\hline Гипоарктическая & 4 & - & - & 4 & 16.0 \\
\hline Бореальная & 15 & 3 & - & 18 & 72.0 \\
\hline Горная & 1 & - & - & 1 & 4.0 \\
\hline Плюризональная & - & - & 1 & 1 & 4.0 \\
\hline Всего: & 21 & 3 & 1 & 25 & 100.0 \\
\hline Доля, \% & 84.0 & 12.0 & 4.0 & 100.0 & \\
\hline
\end{tabular}

флоры тундровой зоны северо-востока европейской части СССР (Мартыненко и др., 1987) и 19,4 \% от состава бриофлоры окрестностей Харбейских озёр, выделенной Г.В. Железновой (1978). По результатам наших исследований ранее опубликованный список бриофитов (Железнова, 1978) был дополнен семью видами (Calliergon megalophyllum, Drepanocladus sendtneri, Mnium stellare, Philonotis caespitosa, Polytrichum swartzii, Sphagnum flexuosum, S. subsecundum).
Наибольшим видовым разнообразием обладают семейства Calliergonaceae (5 видов), Sphagnaceae (4) и Mniaceae (4).

Бриофлора Харбейской озёрной системы почти целиком (табл. 5) состоит из широкоареальных видов, распространённых преимущественно в пределах Голарктики, что свойственно для флор мохообразных северных территорий Евразии (Железнова, 1994; Шубина, Железнова, 2002). В целом же бриофлору Харбейских озёр можно охарактеризовать как 
Таблица 6. Распределение числа видов мохообразных флоры Харбейских озёр по гидроэкогруппам

\begin{tabular}{l|c|c}
\hline \multicolumn{1}{c|}{ Гидроэкогруппа } & Число видов, шт. & Доля, \% \\
\hline Гидрофиты & 8 & 32.0 \\
Гигрогидрофиты & 1 & 4.0 \\
Гигрофиты & 9 & 36.0 \\
Гигромезофиты & 3 & 12.0 \\
Мезофиты & 4 & 16.0 \\
Всего: & 25 & 100.0 \\
\hline
\end{tabular}

преимущественно бореальную с участием гипоарктических видов.

Бриофлора Харбейских озёр, как и флора сосудистых растений (табл. 3), почти наполовину состоит из гигрофитов и гигромезофитов (табл. 6). Гидрофиты, уступая гигрофитам по числу видов во флоре озёр, занимают лидирующие позиции в структуре сообществ, нередко формируя монодоминантные куртины (Warnstorfia exannulata) на защищённых от волнобоя мелководных участках озёр.

\section{Макроводоросли}

В растительном покрове озёр Харбейской озёрной системы отмечен один вид макроводорослей: космополитный мезофильный гидрофит - Nitella flexilis (L.) C. Ag. (определение Р.Е. Романова (ЦСБС СО РАН)). Единичные экземпляры вида обнаружены в составе разреженного сообщества Arctophila fulva на прибрежном песчано-гравийном мелководье (глубина 0,8-1,0 м) у восточного берега оз. Большой Харбей близ протоки в оз. Малый Харбей.

Поскольку основная задача исследования состояла в выявлении разнообразия высших макрофитов, внимание макроводорослям практически не уделялось. Сведения о них носят сугубо информационный характер.

\section{Заключение}

Флору Харбейской озёрной системы формирует 91 вид. Из них 65 видов сосудистых растений, 25 видов мохообразных и 1 вид харовых водорослей. На мелководьях оз. Большой Харбей отмечен редкий для Европейского Северо-Востока России вид Potamogeton subretusus. Ведущие позиции по числу видов среди сосудистых растений занимают семейства Poaceae, Potamogetonaceae, Cyperaceae и Ranunculaceae. Среди мохообразных - Calliergonaceae, Sphagnaceae и Mniaceae. В гидроэкологическом спектре флоры сосудистых растений и мохообразных наблюдается явное преобладание гигрофитов. Соотношение трофоэкологических групп флоры демонстрирует её приуроченность к мезотрофным местообитаниям. Географическая структура флоры Харбейских озёр - как сосудистых, так и мохообразных в полной мере отражает их зональное положение: среди сосудистых преобладают виды арктоумеренной широтной группы, среди мохообразных - бореальной с участием гипоарктических видов.

\section{Благодарности}

Выражаю признательность д.б.н. Г.В. Железновой (ИБ Коми НЦ УрО РАН) за определение сборов мохообразных, к.б.н. Р.Е. Романову (ЦСБС СО РАН) за определение 
сбора харовых водорослей, студенту СыктГУ

Е.Н. Сергееву за помощь в проведении экспедиционных работ.
Работа выполнена в рамках Программы фундаментальных исследований «Арктика» УрО РАН проект № 12-4-7-006-АРКТИКА.

\section{Список литературы}

1. Алисов Б.П. (1969) Климат СССР. М.: изд-во МГУ, 128 с.

2. Атлас по климату и гидрологии Республики Коми (1997). М.: Дрофа, 116 с.

3. Бобров А.А. (1999) Флора водотоков Верхнего Поволжья. Бот. журн. 84 (1): 93-104.

4. Железнова Г.В. (1994) Флора листостебельных мхов европейского Северо-Востока. СПб.: Наука, 194 с.

5. Игнатов М.С., Афонина О.М., Игнатова Е.А. (2006) Список мхов Восточной Европы и Северной Азии. Arctoa 15: 1-130.

6. Катанская В.М. (1981) Высшая водная растительность континентальных водоёмов СССР. Методы изучения. Л.: Наука, 187 с.

7. Лазаренко А.С. (1956) Основні заходи классифікаціі ареалів листяних мохів Радянського Далекого Сходу. Укр. бот. журн. 13 (1): 31-40.

8. Мартыненко В.А., Гецен М.В. (1978) Equisetophyta, Anthophyta. В: Флора и фауна водоёмов Европейского Севера. (На примере озёр Большеземельской тундры). Л.: Наука, с. 161-165.

9. Мартыненко В.А., Железнова Г.В., Гецен М.В., Улле З.Г., Лавренко А.Н. (1987) Флора северо-востока европейской части СССР как ботанико-географическая система. Научные доклады, Коми филиал АН СССР, 24 с.

10. Одум Ю. (1975) Основы экологии. М.: Мир, 740 с.

11. Папченков В.Г. (2001) Растительный покров водоемов и водотоков Среднего Поволжья. Ярославль: ЦМП МУБиНТ, 200 с.

12. Папченков В.Г., Щербаков А.В., Лапиров А.Г. (2006) Рекомендуемые для использования общие понятия гидроботаники. В: Материалы VI Всеросс. школы-конференции по водным макрофитам «Гидроботаника 2005». Рыбинск: Рыбинский дом печати, c. $377-378$.

13. Растительность европейской части СССР (1980) Л.: Наука, 429 с.

14. Раменский Л.Г., Цаценкин И.А., Чижиков О.Н., Антипин А.Н. (1956) Экологическая оценка кормовых угодий по растительному покрову. М.: Сельхозгиз, 472 с.

15. Ребристая О.В. (1977) Флора востока Большеземельской тундры. Ленинград: Наука, 334 с.

16. Свириденко Б.Ф. (2000) Флора и растительность водоёмов Северного Казахстана. Омск: ОГПУ, $196 \mathrm{c.}$

17. Секретарёва Н.А. (2004) Сосудистые растения Российской Арктики и сопредельных территорий. Москва: КМК, 129 с.

18. Тетерюк Б.Ю. (2012а) Флора древних озёр Европейского Северо-Востока России. Известия Самарского научного центра 14 (1): 82-90.

19. Тетерюк Б.Ю. (2012б) Флора и растительность древних озёр Европейского Северо-Востока России. СПб: Наука, 237 с.

20. Титов Ю.В. (1975) Некоторые предложения к усовершенствованию экологической терминологии. Экология 4: 13-19. 
21. Флора и фауна водоёмов Европейского Севера. (На примере озёр Большеземельской тундры) (1978). Л.: Наука, 192 с.

22. Хантимер И.С. (1974) Сельскохозяйственное освоение тундры. Л.: Наука, 287 с.

23. Черепанов С.К. (1995) Сосудистые растения России и сопредельных государств (в пределах бывшего СССР). СПб.: Мир и семья-95, 992 с.

24. Шляков Р.Н. (1961) Флора листостебельных мхов Хибинских гор. Мурманск: Мурманское книжное изд-во, 252 с.

25. Шубина Т.П., Железнова Г.В. (2002) Листостебельные мхи равнинной части средней тайги европейского Северо-Востока. Екатеринбург: изд-во УрО РАН, 158 с.

26. Щербаков А.В. (2003) Изучение и анализ региональных флор водоёмов. В: Гидроботаника: методология, методы. Рыбинск: Рыбинский дом печати, с. 56 - 69.

27. Юдин Ю.П. (1954) Геоботаническое районирование. В: Производительные силы Коми АССР. Т. III. Ч. І. М.: изд-во АН СССР, с. 323-359. 